\title{
Correction to: Osteopontin/secreted phosphoprotein-1 behaves as a molecular brake regulating the neuroinflammatory response to chronic viral infection
}

Farina J. Mahmud ${ }^{1}$, Yong Du², Elizabeth Greif' ${ }^{1}$, Thomas Boucher ${ }^{1}$, Robert F. Dannals², William B. Mathews ${ }^{2}$, Martin G. Pomper², Polina Sysa-Shah², Kelly A. Metcalf Pate ${ }^{3}$, Claire Lyons ${ }^{3}$, Bess Carlson ${ }^{3}$, Maria Chacona ${ }^{1}$ and Amanda M. Brown ${ }^{4 *}$

Correction to: J Neuroinflammation 17, 273 (2020) https://doi.org/10.1186/s12974-020-01949-4

Following publication of the original article [1], the authors noticed that there are several images for Fig. 2 that are missing from the published article. Presented here is the corrected Fig. 2. Also, the original article has been updated.

\section{Author details}

'Department of Neurology, Johns Hopkins University School of Medicine, Baltimore, MD 21287, USA. ${ }^{2}$ Department of Radiology and RadiologicalScience, Johns Hopkins University School of Medicine, Baltimore, MD 21287, USA. ${ }^{3}$ Department of Molecular and Comparative Pathobiology, JohnsHopkins University School of Medicine, Baltimore, MD 21287, USA.

${ }^{4}$ Department of Neurology and Neuroscience, Baltimore, USA.

Published online: 17 November 2020

\section{Reference}

1. Mahmud FJ, Du Y, Greif E, et al. Osteopontin/secreted phosphoprotein-1 behaves as a molecular brake regulating the neuroinflammatory response to chronic viral infection. J Neuroinflammation. 2020;17:273 https://doi.org/ 10.1186/s12974-020-01949-4.

The original article can be found online at https://doi.org/10.1186/s12974020-01949-4.

* Correspondence: abrown76@jh.edu

${ }^{4}$ Department of Neurology and Neuroscience, Baltimore, USA

Full list of author information is available at the end of the article

(c) The Author(s). 2020 Open Access This article is licensed under a Creative Commons Attribution 4.0 International License, which permits use, sharing, adaptation, distribution and reproduction in any medium or format, as long as you give appropriate credit to the original author(s) and the source, provide a link to the Creative Commons licence, and indicate if changes were made. The images or other third party material in this article are included in the article's Creative Commons licence, unless indicated otherwise in a credit line to the material. If material is not included in the article's Creative Commons licence and your intended use is not permitted by statutory regulation or exceeds the permitted use, you will need to obtain permission directly from the copyright holder. To view a copy of this licence, visit http://creativecommons.org/licenses/by/4.0/ The Creative Commons Public Domain Dedication waiver (http://creativecommons.org/publicdomain/zero/1.0/) applies to the data made available in this article, unless otherwise stated in a credit line to the data. 


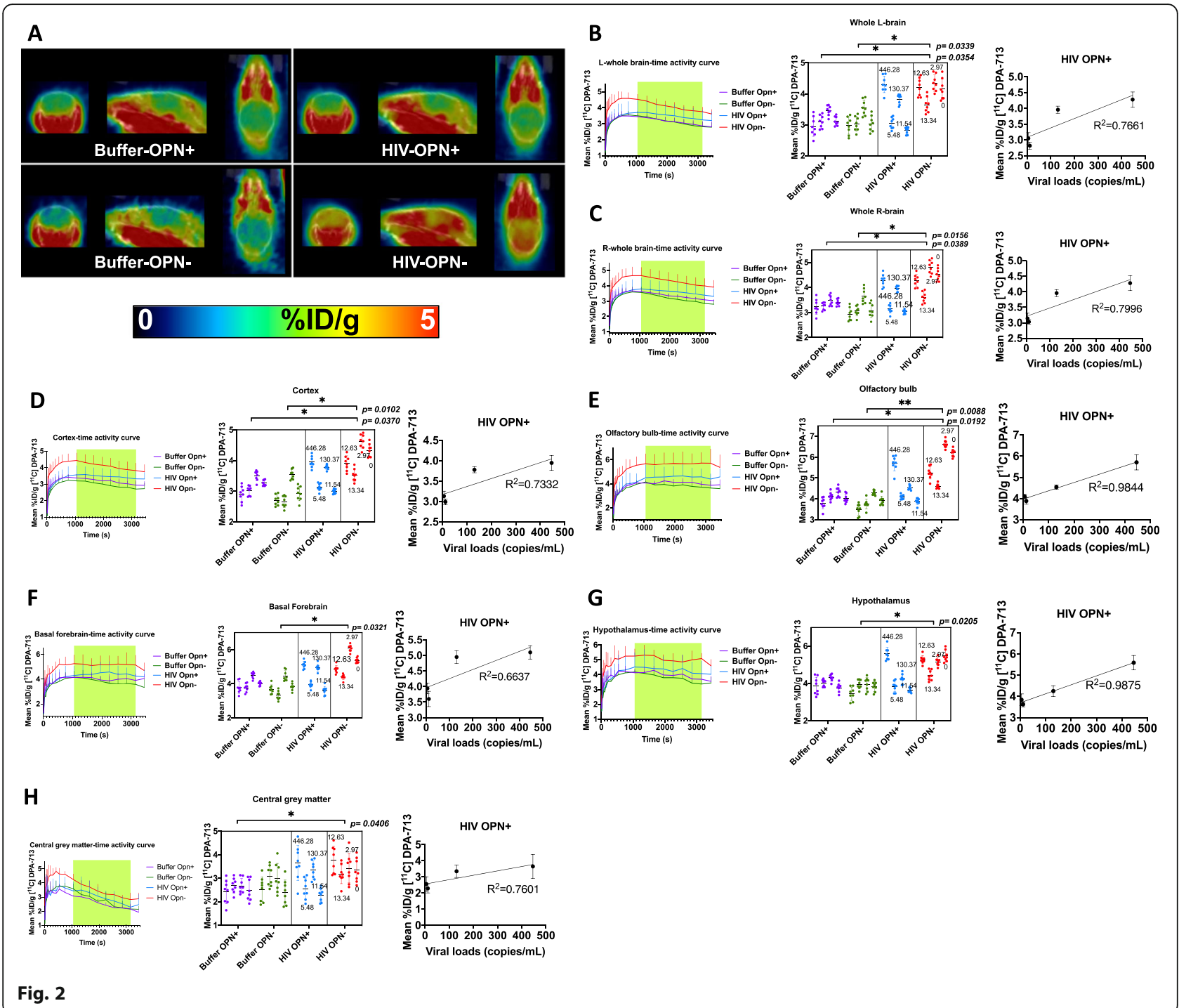




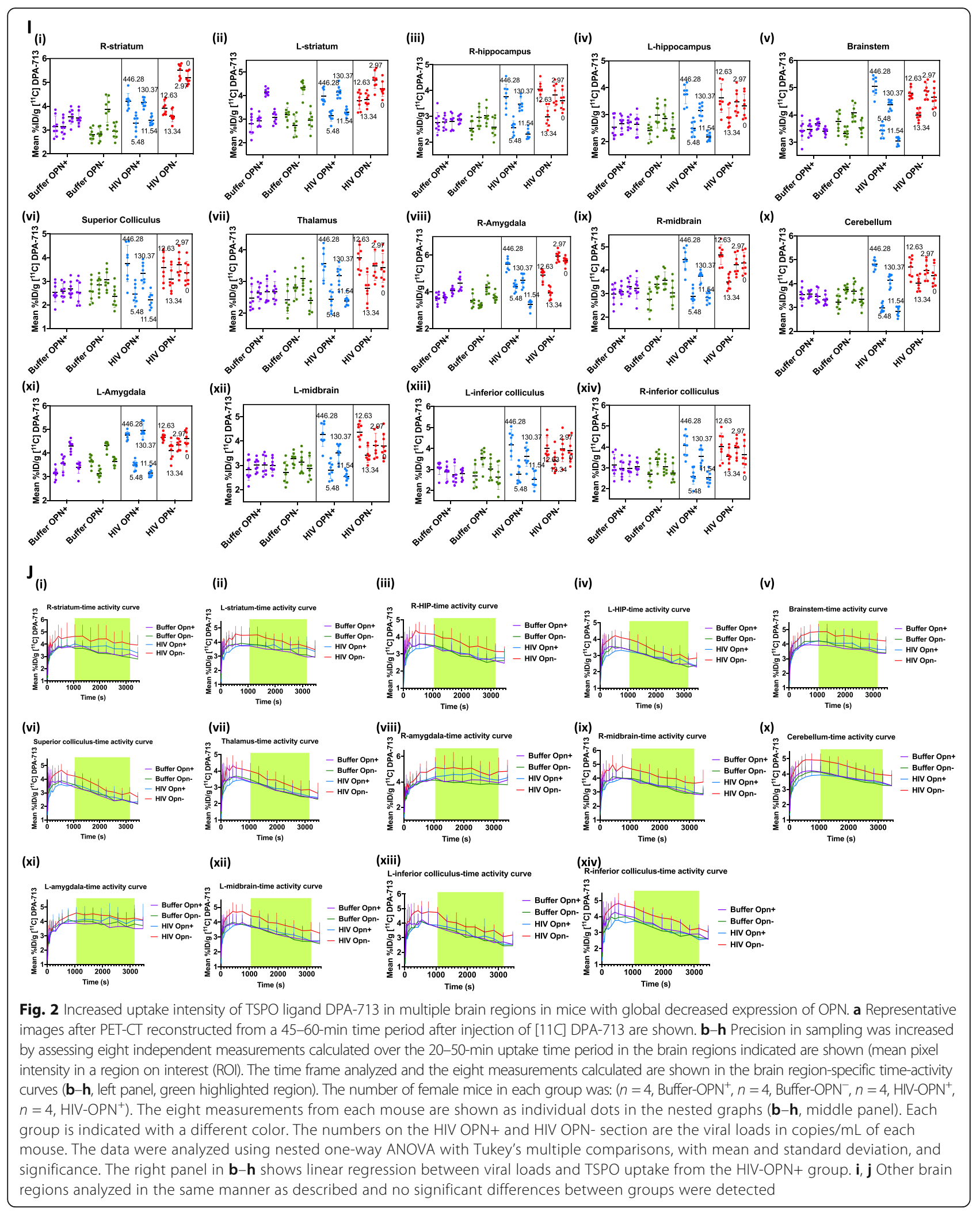

